\title{
Affective and Aspirational Dimension of Political Reality. Is Knowledge of Politics Still the Domain of Political Scientists?
}

\author{
Afektywny i postulatywny wymiar rzeczywistości politycznej. \\ Czy wiedza o polityce jest jeszcze domeną politologów?
}

\section{- Abstrakt •}

Współczesna wiedza o polityce czerpie z różnych zasobów, dla których akademickie środowiska politologów nie są wcale bezalternatywnym emitentem informacji. Postuluje się nie tylko poznawczy egalitaryzm, ale również wybiera się wiedzę adekwatniejszą, ponieważ kryterium oceny to jej przydatność do praktycznego wykorzystania. W ten sposób przestajemy dostrzegać, że wiedza par excellence naukowa najpierw przenika się z potocznym rozumieniem i wyjaśnianiem polityki, a w kolejnym kroku traci swój wyjątkowy charakter, zakorzeniony w metapolitycznym dociekaniu naukowym. Empiryczne efekty, w przypadku analizy polityki, sprowadzane są do wywarcia wpływu na odbiorcę. Skutkiem tego nauka o polityce zyskuje profil pracy zarobkowej, której osiągnięcia w niewielkim stopniu przystają do postulowanej rzeczywistości politycznej.

Słowa kluczowe: polityczność, publicysta, politolog, wiedza o polityce, nauka o polityce, teoria polityki, metateoria polityki

\section{- Abstract •}

Modern knowledge about politics draws from a variety of resources for which the academic environment of political scientists is not at all a nonalternative issuer of information. Not only cognitive egalitarianism is postulated, but also more adequate knowledge is chosen, because the criterion of evaluation is its suitability for practical use. In this way, we stop to recognize that knowledge, par excellence scientific, first permeates with the colloquial understanding and explaining of the politics, and in the next step loses its unique character, rooted in metapolitical scientific research. Empirical effects, so in the case of political analysis, are brought to influence the recipient. Because of this science of politics is gaining a profile of gainful employment, whose achievements little fit into the postulated political reality.

Keywords: the Political, publicist, political scientist, political knowledge, political science, Political Theory, Political Meta-theory 
"And all this science I don't understand It's just my job five days a week"

Elton John, Rocket Man

\section{The Dispute over the Scientific Context of the Political}

The political phenomena subjected to a standard observation and description seem simple to analyze, so they make us engage in a debate easily, regardless of our competence. We are, despite the erroneous declarations of being apolitical, part of the processes happening in the domain of the political. A large part of this group has the ambition not only to deal with politics in some active dimension, but very often they postulate the reality that is most anticipated by themselves. This should not be surprising, because it is a typical feature of Hobbes' human rivalry, happening on many levels. This should also not be strange to professional researchers, because supposedly objective need of scientific achievements is yet subjectively motivated. Additionally, it itself is evaluative. It might appear a question at this point whether there is a need to take into account the academic knowledge of politics, since its practical function is not yet reduced to the idea that political science education would provide for the right to practice the profession of a politician. It is difficult to assume that superficial awareness of political issues is a threat comparable to medical malpractice. Let's try to imagine the degree of involvement of medical and political knowledge in the life of one citizen. Excluding emergency situations, the political decisions are the vast majority of impacts on an individual, although they influence on the social group most often en bloc by universalized solutions. Thus, if the self-treatment is not completely prohibited, but is severely limited by the availability of regulated drugs and medical procedures, so much you can politicize yourself and others without any restrictions. Another dilemma involves consideration of the division into the ongoing social and political phenomena, as well as those which are the consequence of perceptions and judgments about the content of the political. The political in its definitional disorderliness does not allow arbitrary usurpations. Considering the primary form, we should pay attention to the actual processes taking place, in addition to those which are an attempt of imagination of concepts. It is not difficult to note that the most spectacular presentations of the public discourse are full of not opinions but expressed emotions, so they are not thoughts, but feelings and sensations. In this place the presence of the political scientist may seem superfluous, unless you entrust him with the role 
of the therapist of unresolved "political" dilemmas. The election of Donald Trump as the $45^{\text {th }}$ president of the United States or Brexit are the events changing the established ways of commenting policy for the purposes of political journalism. You might at this point draw the line separating a cognitive judgment from others. However, this is only an illusion. Unfortunately, political science in all its frailty has absorbed and adopted emotions of the political. Until recently, it was so that slogans filled with emotion served to win political battles, but today they serve to understand the meaning of the projects of the most important decision makers. One presents the characteristics of how Trump "feels" foreign policy, what he "believes" and how it will affect the world economy, or in no less mournful tone it is announced: "Europe excludes Britain" (Elliot, 2016). It is not far from the claim that Trump has gained knowledge of Central and Eastern Europe from his two Slavic wives. "What happens now?" becomes an often-repeated phrase, which is rather difficult to be regarded as an attempt to explain the observed changes in the direction of Western politics. However, an unresolved issue is the recognition whether we are always dealing with the same knowledge about politics. Bearing in mind that knowledge is a form of science and like the comments in the media is public and generally available without restriction, let us consider yet another issue. The election of Donald J. Trump in political science analysis seems to be something different from the logic professed by the media. The dominance of the newspaper New York Times in the US, and perhaps even the global media system, is manifested through forcing interpretation of policy issues so that it demonstrates their possible deviations from the postulated state. It is not surprising when the most famous American title presents the elements of the policy of the new president as leaving and threatening the American tradition (Taub, Fisher, 2017), regardless of the fact that "Americanism" used in such a way is at most a euphemism serving elitism and exclusivity of the historical role of establishment. It is also significant that in another place, NY Times attacks the same Trump just for the excitation of the American national tradition, calling it "white nationalism" (Rappeport, Weiland, 2016). In another example, the Washington Post describing the new Polish government of Law and Justice prophesies clearly that we are dealing with the triumph of anti-intellectualism, and in this description it uses an inseparable "what happens" (Faiola, 2016). These few illustrations describe the tendency of the impact of the most influential media on the process of understanding the political. This understanding is largely authoritative. It leaves the reader in a situation of an apparent alternative stored in a Manichean choice between the forces of light and darkness. Does, therefore, political science still need a clear separation of content and judgments largely based on doctrinaire thinking? Is it worth once again reminding the 
existence of the invisible demarcation line which separates the theoretical from postulative content? The task we can give political scientists is to examine the content of the political in terms of their creation and the description and analysis by the creative entity. The duty of political scientist is still analysis of rational (scientific) image of politics. In addition, he or she will be forced to examine the motives and consequences of imposing the journalistic image of political phenomena, supported by the claim to infallibility. So, we include politics, politicians and creators of ideas about politics into our considerations.

The marriage of political scientists and political commentators is becoming more and more problematic on the level of meta-theory of political science studies. It could be argued that this observation is not particularly dangerous for a standard consumer of policy content. In terms of the everyday logic of communication it can be considered that corresponding of the journalistic and political science terms allows us to discover, and in the next step, boost practical and useful function of the discipline of the social sciences. The alliance being the consequence of managing the content of public debate requires the use of the same set of concepts and designates. In the course of engagement in current policy judgment, as well as in the face of the intensity of the pursuit of social life, men of science began to confuse the theoretical and metatheoretical contents. In a classic essay Jan Woleński stated that "explaining a fact is a theoretical problem, and defining the object of a science or theory is a metatheoretical problem" (1975). Although for many years we, political theorists, have been in discussions about the subject material of political science, and what is more, for a long time we have declared that this fundamental issue has long been resolved, we identify substantial resources of political science periodicals, which prove rather a lack of acceptance for this postulate. Taking into account the metatheoretical qualification reveals pre-scientific model of practicing political science, of which representatives seek to legitimize the value of communication of media, making their observations a full-fledged component of the research. "Which came first the chicken or the egg?" This dilemma illustrates the doubt whether political scientists have a real impact on "other people of politics", that is politicians or journalists, or if they try to append ex-post scientific rationality to what takes place in their area of interest. We come therefore to the doubts that Richard Skarzyński expressed about entangling the Polish political science in the "production of" common knowledge (Skarzyński, 2012a; 2014). We must realize the seemingly banal conclusion that people separated from scientific activity use the colloquial understanding of politics. It is the resultant of lack of interest by those who control the scientific process and live in isolation from the commonly seen reality (Feynman, 2005). That detachment from reality, which 
Feynman shows, plays an important role in assuming the right of everyone to such understanding of it that becomes an emanation of wishes towards it. Mixing in the field of analysis of political phenomena, scientific and journalistic thinking leads to attempts to answer the most irrational questions. If there is no confirmation of the facts you can always protect yourself with assumption and triumph that you have built the fundamental problem, for which there is no answer. This situation illustrates the scheme of scientific deactivation of social problems, because every man in the public space is capable of creating a research postulate. Moreover, they do not bother to try to search the proof of veracity, but the burden rests on those who have referred to such evidence in science so far (onus probandi). This leads to the need to replace the conventional recognition of proof of the phenomenon with the requirement to prove that it was not as "axiomativists" want it. Since there is no evidence to the falsity of the thesis it is publicly recognized as valid. Assumptions are not valid, but opinions which someone wants to be treated as a scientific conjecture, but it prevented by objective inability to make these presumptions undergo verification, confirmation or falsification. At this point we come to the problem of belief of which Adam Grobler writes (2016). The assertion is complemented by the reference to "the existence of widespread belief" on the subject. Statistical confirmation of an assumption means its rooting in the debate about political phenomena. Scientific legitimacy of assumptions and reduction deriving from the public debate has already become the scourge of modern political science. The proliferation of forms and tools of communication creates a permanent stream flow of information. The concepts are gaining inappropriate referents, and the world of science deals with explaining of unverified information in real time, without addressing the verification of their authenticity. Each comment on the political phenomena due to the existence of social media becomes part of the image of politics, but at the same time it is strongly deformed. In the days before the massification of public communication scientific theories related to the problems developed in scientific institutions, today they have been made a form of treatment of scientific phraseology of senility of reducing and postulative observation. This is compounded by an objective difficulty to reject the interpretation of phenomena, which exceed the grounding in the available evidence. The problem of the political is a very wide cognitive compromise in the area of scientific inquiry of political scientists. Nevertheless, annexing political contents, as an excuse for their own subject of interest motivated by tendency and popularity expressed in media interest, arouses doubts of metatheoretical nature. Science can skip the moral arguments of that choice (e.g. the question of gratification), unless we deal with the fabrication of knowledge which claims the right to scientification. 
It would seem that it should be strictly rejected because there is still a dividing line between what is and isn't considered scientific. Therefore, seeking to examine the strategy of understanding from the level of epistemology, we would have to impersonate (Dilthey's Verstehen) those who take on the situation of politicians. We are dealing with a form of meta-incarnation, which results in an attempt to rationalize behaviors to a large extent based on the affective understanding of the political. Following this trail, we find, however, the concerns expressed by theory-laden observation or immersion in context. Our way of thinking to a large extent depends on the well-established ways to identify phenomena. So, we turn naturally to the intentions and reasons that become this time a component of our explanation (Grobler, 2006). So, political events are subject to explain the strategy of integration (understanding naturalism; Topolski, 1978; Młyńczyk, 2015). In the case of the context we understand a fragment of reality in strictly temporal and always spatial terms. Taleb points out that the context relationship of our minds allows us to understand an event in one place, while changing it and the time causes us a feeling of powerlessness in the face of something that we do not think is an identical situation (Taleb, 2013) ${ }^{1}$. Politics is full of this kind of phenomena, both on the Potomac, and the Vistula River, this algorithm does not change its components. People usually devote as much attention to recognition of the truth of their own understandings as to demonstrate the falsity of their adversaries. They do not see, or try not to see that their arguments are exact repetition at another time, although used by their opponents. It is therefore a degree of association and dissociation, and those are crowned with friendship or hostility (Schmitt, 2000; Skarzyński, 2012b). Being heard, they are radically rejected, which erroneously suggests that each political phenomenon is a phenomenon of uniqueness. This is therefore a political distinction or colloquially a worldview one, not the right to priority to use an argument. Individual political events can be largely presented at the level of identification. Their uniqueness and intransitivity is only a postulate of the parties directly involved in the political dispute. Let us consider one more dissonance. The information and opinions expressed in the media are subject to reduction and proceeding, and although we all are aware of this, we are accustomed to see the whole issue in them. Meanwhile, science is an escape from the simplification and briefness. It does not have, at least at the formal level, time

${ }^{1}$ An interesting illustration of this issue can be a planned purchase by the Ministry of Defence of the so-called "tactical pens", which will be equipped with a blade, glass breaker and a LED flashlight and allow you to write at any angle in temperatures from 37 to 120 degrees Celsius. While it is easy to understand the tactical possibilities of this pen in case of a direct threat, it is difficult to imagine the need for conventional use, i.e. writing anything at temperatures above boiling water. 
limit. However, it is only an assumption, because political scientists depend on two necessities: systemic and professional. The first is the parameterization of test results, which may not reflect the correct value of science. The second is expiring the "weighty" political events, describing of which in monographs is often merely their logging (Smith, 2014). Therefore, the temptation of the marriage is probably great. Especially when it seems that the knowledge of political science can be easily produced, which, however, does not mean that all human activities can be called, without any objections, politics (Skarzyński, 2011).

\section{The Scientific Theory of What is and is Not Political}

Experiencing the world of politics and the observation of the phenomena leads all involved entities to be active. The practical function of a political science debate can be manifested in an attempt to correct the directions of activities under the analysis of the decisions made by policy makers. You could at this point ask a question about Lasswellow's system functionality. Analyzing the political theory of the American political scientist, Leszek Porębski reminds the distinction Lasswell used between a conventional political system (government and its institutions) and the functional model (men of influence) (Porębski, 2007). We are all part of the political reality that affects us in return. And this brings us to the problem of influence, recognized as a fundamental objective of politics in terms of Dahl and Stinebrickner (2007). On the level of theory, both Lasswell and Dahl refer to the issue of "influence". Lasswell sees a criterion of political roles in different kinds of activities whose common denominator is the impact on the functioning of a community (Lasswell, 1948; Porębski, 2007). Dahl and Stinebrickner state explicitly: "politics is simply influencing" (Dahl, Stinebrickner, 2007). Treating literally these declarations, journalists should be given unlimited ability to produce this particular politics. The dispute about what the political parties, of which would be political scientists and political journalists, is not questioning the right to a certain version of political mobilization, but to recognize what is theory and metatheory of politics. Non-scientific environments engaged in producing political science produce today a kind of pressure, immersed in the rhetoric of politics, where it is assumed no need for the scientific basis of the contents which educate the public. Hence rational basis of politics is rejected, because rhetoric regulates everything. Lack of major cognitive principles introduces a general freedom, within that everyone feels the political tension freely, and his knowledge is not subject to 
falsification. There is no ambition of scientific veracity, and its sole purpose is to achieve a level of egalitarianism - everyone has the right to analyze politics. Of course, it is much easier to analyze your own imaginations. Then we see the process of transition from explaining politics towards controlled speech on request, which is epistemologically useless (Smith, 2014). Political scientists willingly infringing on the conventional exchange of roles, or extracting concepts from the extended rhetoric of influence, devastate cognitive assumptions of their own profession. Nominally they are still members of the guild, but moving to the pre-theoretical level they join egalitarists, giving evidence that the science of politics is only part of low-efficient academic profession, while the ubiquity of empirical politics allows to operate on the principles of the presumption of authority. However, the truth sought in universities does not depend on contingent profits, but it is self-sufficient (Smith, 2014). The resulting tensions do not affect cognitive issues in political science, but arise from the selection of political scientists "from their own camp". Due to the principle that excellence and wisdom is a function of support their own postulates, the media choose political issues and determine analysts' professionalism. In a critical lecture on the reductionist vision of the policy, Skarzyński stated: "essentially, there is not a kind of social activities, which could not be attributed political status. Especially when we are dealing with the debate carried out in the media, where much more attention is given to consumers' beliefs, rather than to the correct use of concepts and precise expression" (Skarzyński, 2011). It is impossible not to agree with the author recognizing that "getting to the concept of influence" as a feature of political science inquiry, not a definition of politics par excellence. Simplifying, it is reducing the phenomenon of the most common features. As Stefan Nowak notices, the cognitive entities select stimuli that comes to them, limiting their attention to the really few (Nowak, 2010). It's hard not to notice that during the war, military operations are under way, but is it the only one of its important features? Thus, although the influence is almost the most common piece of political actions, however, treating it autotelically stops us before reaching the political objective, whose it can only be a tool. It is worth considering what consequences this brings in the field of metatheory and theory of politics. Deliberating together participants of political life present a set of interpretations of what they consider to be the core of the judgment of reality. There is surplus of the opinions expressed by the media people trying to get the desired effect by imposing interpreted elements together with their correct interpretation. They achieve the influence expressed by the closure of the debate due to the recommended criteria. They do not go beyond this circle, increasingly floundering in the contradictions and antagonisms. Dialectics stops them in a place where science of politics 
requires a theoretical explanation and not adhering to demanding reductionism. A political feature, however, ceases to have its properties when its representativeness for the problem is only enforced in the form of a request. It would be a cognitively honest settlement to argue that although journalists represent a fragment of knowledge about the political phenomenon, the key is, however, its quantitatively small range. Usually the used simplifications allow to develop a universal key of interpretation, and its strength is to rely just on a kind of uncertainty. Then it fits almost any situation, not having a clearly extraordinary character. In addition to the aforementioned strategy of incarnation into a problem, science is based on two key elements of reasoning: explaining and predicting. Assuming colloquial knowledge of politics as equivalent of the scientific one, we allow the entities representing it to transfer an opinion from present into the unknown. This happens when the simplified prediction is the shift of postulated reality into the future, with the hope that it will happen, despite major attempts to challenge by the people seen as opponents of this order. Such forecasting reminds predicting snowfall in the temperate climate zone, in the mountains and necessarily in the winter months. Repeated reproduction of this phenomenon takes place, but on the exclusive basis. In contrast to a political event, interpretation of a desideratum deliberately ignores the facts and evidence that do not match the created image. Knowledge promoted by the media is a double denial of political science. They defend their own interpretation on the principle of the right to a universal key, and the political commitment results in limiting within the integrity of the arguments. Hence, we see that understanding and explaining phenomena and perceptions of politics produce the contradiction which the media ignore, as the impact expressed by the recommended model of reality, and even involuntary commercial success confirm them in the validity of their own views. Faced with such motives science seemingly looks helpless. Imposing the image of political reality is fundamentally different from that in which the study of phenomena considered political is carried out. Far more unbinding rules of exploring the world of politics, as well as the need for simplification, increase the chances of getting messages to the audience before political scientists do this, not in the form of a comment but the implementation of the rules of science. The time and the attractiveness of the editorial content can produce another social condition, which is subject to the following conceptualization. In other words, in the political science we do not deal with a strictly isolated political situation, as we analyze the phenomena, which are subjected to permanent politicization. Theoretically, the media are always one step ahead of political scientists. The rational model of describing the study of politics has certainly a higher cognitive status, although it is also quite widely ignored. This is due to the discovery 
that the management of knowledge about politics, even colloquial and simplified, brings specific perks in our world.

Part of political scientists' knowledge being by far abstract is not subjected easily to falsification, or even prevents it. Hence the clear claims of inductionists to perceive achievements of political sciences in the perspective of their probability. This requirement only applies to professional and advanced scientific inquiry of political science. It does not include other professions, which effectively consume any format of knowledge about politics. From the scientific theory level, following Popper, one can reject inductionism as the position of stating the veracity of the universal statement through the transfer of the result of observation of the experience described with a single sentence (Popper, 2002), which would not hinder the political journalists to claim that probably all swans are white (Taleb, 2014). In fact, the problem is not on the side of proof of an event. It is also not a dispute about facts, as well as not entirely comes to a condition that commonly is called "post-truth". I mention this concept also to illustrate how easily capacious definitions, suggesting the existence of knowledge par excellence, absolute knowledge, gain popularity (Kołakowski, 2009). Of course, we do not need to reject it instantly, because it can serve as a question about the condition of contemporary political science, but nothing more. The degree of intensification of political comments has created three types of knowledge about politics: colloquial, scientific, and a hybrid of both. Their periodic recognition stems from the relevance of practical use in the social space. Authority arising from the knowledge being the result of medical research quite effectively reduces the influence of the world of charlatans. The scientific for the greater part displaces prejudices and superstitions, although free flow of information has certainly led to a state in which people heal themselves by drawing an analogy of the virtual fate of people affected by "similar symptoms". By moving it to the ground of political knowledge, it is not so easy to qualify the views and opinions of the media to the set of political homeopaths. Political judgments always contain a sufficient level of the active ingredient, which could cause far-reaching political implications. Undoubtedly, such an example is the modern phenomenon of micro-blogging on Twitter, allowing to convey in one hundred forty characters the intentions or a comment having a big emotional charge, in addition going on almost in real time. Although the number of characters for a single speech is actually limited, yet the number of consecutive "twits" is unlimited. A terse political message has become in recent years an essential tool for provoking behavior and political choices of citizens. Twitter has become the field of the highest activity of the political commentators' community who have received effective instrument for shaping and consolidating opinions then assimilated 
by the citizens. Virtual social movement of "Twitter users - political commentators" decided on the shape of modern democracy, taking over a large part of real-time tasks of institutional politics. The experiential dimension of politics is not subject to the standard proofs, and its experience comes down to postulate a fact, at the cost of displacing theoretical analysis models for which there is no demand in society. Knowledge in the instant form, in the opinion of many people, effectively fulfills the task of political education. If, therefore, political publicists and quasi-experts can, in their own mind, effectively influence, enjoying this emotion, they do not find reasons to question the versatility and usefulness of knowledge of politics based on emotions and opinions, rather than on an analysis of thoughts or constructing research hypotheses. Although there are still persistent rules of qualifying scientific and non-scientific knowledge, interference of carriers of colloquial content in metapolitical core of academic research does not arouse widespread opposition among professional political scientists.

\section{Conclusions}

Policy in the most quantitatively dominant form is going on through the images. These in turn are an inherent connection with an extensive phraseology, whose primary aim is the creation and self-creation of political actors. The development of methods of communication has also built a surplus of information about people and political phenomena, and societies are trying to consume it. The processes of building authorities, bringing secondary charisma (Karwat, 2004), are an interesting field of exploration, in order to try to move away from the oversupply of content whose scientific value is based on the notion of promoting post-politics or nearing ostentation speculative judgements. Does it, however, mean a return to the days of the knowledge generated from the authority and faith? Knowledge of political scientists is rooted in the metapolitical traditions, imposing on them versatile in terms of the requirements of building cognitive achievements of their own discipline. There are no shortcuts if the common goal remains a concern for the scientific standards of our knowledge. However, if we as political scientists mistakenly assume egalitarian model, promoting a desire to debate rather than its quality, then gradually we displace ourselves from the scientific vanguard, giving evidence of excessive maintenance costs of our profession that could be brought down to a popular hobby, after all. Called by mistake work, five days per week. 


\section{References:}

Dahl, R.A., Stinebrickner, B. (2007). Wspótczesna analiza polityczna. Warszawa: Wydawnictwo Naukowe Scholar.

Faiola, A. (2016). In Poland, a Window on What Happens When Populists Come to Power. Retrieved from: https://www.washingtonpost.com/world/europe/in-poland-a-windowon-what-happens-when-populists-come-to-power/2016/12/18/083577e8-c20311e6-92e8-c07f4f671da4_story.html?hpid=hp_hp-top-table-main_poland-802 pm\%3Ahomepage\%2Fstory\&utm_term $=.5203454 \mathrm{~d} 2 \mathrm{~b} 02$.

Feynman, R.P. (2005). Przyjemność poznawania. Warszawa: Prószyński i Sk-a.

Grobler, A. (2016). Dwa pojęcia wiedzy: w stronę unifikacji. Przegląd Filozoficzny - Nowa Seria, 1 (97), 141-160.

Grobler, A. (2006). Metodologia nauk. Kraków: Znak.

Elliot, L. (2016). How America's New President Will Affect the Global Economy. Retrieved from: https://www.theguardian.com/business/2016/nov/09/donald-trump-new-uspresident-america-global-economy-china-mexico.

Karwat, M. (2004). Figuranctwo jako paradoks uczestnictwa: eseje przewrotne. Warszawa: Elipsa.

Kołakowski, L. (2009). Czy Pan Bóg jest szczęśliwy i inne pytania. Kraków: Znak.

Lasswell, H.D. (1948). Power and Personality. New York: W. W. Norton.

Młyńczyk, Ł. (2015). Między kreatywnościa a próżnowaniem. Polityczność dwóch typów idealnych. Warszawa: Elipsa.

Nowak, P. (2014). Hodowanie troglodytów. Uwagi i szkolnictwie wyższym i kulturze umystowej człowieka współczesnego. Warszawa: Biblioteka kwartalnika „Kronos”.

Nowak, S. (2010). Metodologia badań społecznych. Warszawa: Wydawnictwo Naukowe PWN.

Popper, K.R. (2002). Logika odkrycia naukowego. Warszawa: Wydawnictwo Naukowe PWN.

Porębski, L. (2007). Między przemoca a godnościa. Teoria polityczna Harolda D. Lasswella. Kraków: Księgarnia Akademicka.

Rappeport, A., Weiland, N. (2016). White Nationalists Celebrate 'an Aweking' After Donald Trump's Victory. Retrieved from: https:/www.nytimes.com/2016/11/20/us/politics/white-nationalists-celebrate-an-awakening-after-donald-trumps-victory.html?_ $\mathrm{r}=0$.

Schmitt, C. (2000). Pojęcie polityczności. In: C. Schmitt, Teologia polityczna i inne pisma (p. 191-250). Kraków: Znak.

Skarzyński, R. (2011). Mobilizacja polityczna: wspótpraca i rywalizacja człowieka współczesnego w wielkiej przestrzeni i dtugim czasie. Warszawa: Elipsa.

Skarzyński, R. (2012a). Podstawowy dylemat politologii: dyscyplina nauki czy potoczna wiedza o polityce. Białystok: Temida 2.

Skarzyński, R. (2012b). Od chaosu do tadu. Carl Schmitt i pojęcie tego, co polityczne. Warszawa: Wydawnictwo von borowiecky.

Skarzyński, R. (ed.). (2014). Przedmiot poznania politologii: podstawy dyscypliny nauki. Białystok: Temida 2. 
Taleb, N.N. (2013). Antykruchość: o rzeczach, którym stuża wstrzasy. Warszawa: Kurhaus. Taleb, N.N. (2014). Czarny Eabędź: o skutkach nieprzewidywalnych zdarzeń. Warszawa: Kurhaus.

Topolski, J. (1978). Rozumienie historii. Warszawa: Państwowy Instytut Wydawniczy.

Taub, A., Fisher, M. (2017). Trump's Immigration Order Tests Limits of Law and Executive Power. Retrieved from: https://www.nytimes.com/2017/01/30/us/politics/trumpimmigration-muslim-ban.html.

Woleński, J. (1975). Spór o status metodologiczny nauki o polityce. In: K. Opałek (ed.), Metodologiczne i teoretyczne problemy nauk politycznych (p. 32-57). Warszawa: Państwowe Wydawnictwo Naukowe. 